\title{
THE EFFECT OF AIR FLOW RATE ON SINTER YIELD, SINTER STRENGTH AND NI CONTENT IN SINTERING LATERITE NICKEL ORE
}

\author{
FAKHREZA ABDUL* \\ Department of Materials and Metallurgical Engineering \\ Institut Teknologi Sepuluh Nopember \\ Jl. Teknik Kimia, Keputih, 60111, Surabaya,East Java, Indonesia \\ fakhreza.abdul@mat-eng.its.ac.id \\ SUNGGING PINTOWANTORO \\ Department of Materials and Metallurgical Engineering \\ Institut Teknologi Sepuluh Nopember \\ Jl. Teknik Kimia, Keputih, 60111, Surabaya,East Java, Indonesia \\ sungging@mat-eng.its.ac.id \\ ALFIN YURISMAN \\ Department of Materials and Metallurgical Engineering \\ Institut Teknologi Sepuluh Nopember \\ Jl. Teknik Kimia, Keputih, 60111, Surabaya,East Java, Indonesia \\ alfinyurisman@gmail.com \\ * Corresponding author
}

Published 31 January 2020

\begin{abstract}
The depletion of nickel sulphide ore supplies which are usually used to produce nickel metal encourages the use of laterite nickel ore due to the presence of more laterite in nature. Because laterite has a low strength and high water content, a process is needed so that it is used for Mini Blast Furnace, that is sintering. The purpose of this study is to determine the effect of airflow rate on strength, sintering gain and $\mathrm{Ni}$ content on sintering laterite nickel ore. The variation of the air flow rate used are 5.45, 8.22, and $10.59 \mathrm{~m}^{3} / \mathrm{min}$. To know the Ni content, EDX is tested on laterite and sintered. The strength of the sintered produced can be known by drop test. The phases that exist on laterite and sintered are known by XRD testing. The highest sinter yields were found at a flow rate of $10.59 \mathrm{~m}^{3} / \mathrm{min}$ with the acquisition of $12.079 \mathrm{~kg}$ of sinter. The highest sinter strength was achieved when using air flow rate of $10.59 \mathrm{~m}^{3} / \mathrm{min}$ with the shatter index of $65.24 \%$. The highest $\mathrm{Ni}$ content was obtained when using air flow rate of $10.59 \mathrm{~m}^{3} / \mathrm{min}$ with Ni content of $3.8367 \%$. The major phase of sinter are Pyroxene $\left(\mathrm{CaFeSi}_{2} \mathrm{O}_{4}\right)$ and Olivine $\left((\mathrm{Fe}, \mathrm{Mg})_{2} \mathrm{SiO}_{4}\right)$. The best sintered results were obtained in the sintering process with an air flow rate of $10.59 \mathrm{~m}^{3} / \mathrm{min}$
\end{abstract}

Keywords: Nickel laterite ore; air flow rate; sintering

\section{Introduction}

Nickel is one of the most important metals and has many applications in the industry. As a metal for commercialization, nickel is widely used to produce stainless stell or alloys for high temperature applications. In the past few decades, the increased demand for stainless steel has caused a significant increase in ferronickel production of about around $62 \%$ of nickel metal used in stainless steel, about $13 \%$ consumed as superalloys and non-iron alloys because of its corrosion resistance and high temperature resistance (Barkas, 2010).

Nickel ore can be classified into two groups, sulfide ore and laterite ore (oxide and silicate). Even though $70 \%$ of nickel ore is based on laterite ore, $60 \%$ of the primary production of nickel comes from sulfide ore. So far, nickel extraction usually uses nickel sulphide seeds. However, due to the difficulty in finding nickel sulphide ore, the use of laterite nickel ore which has a lower nickel content began to be taken into account. There are 
MATERIALS RESEARCH COMMUNICATIONS 1(1) (2020) 26-33

Fakhreza et. al.

many undeveloped laterite deposits in the world that allow exploitation of laterite to meet demand for nickel. So that nickel production in the future is expected to come from laterite nickel ore. In Indonesia, laterite nickel reserves amount to $15.7 \%$ of the total nickel laterite reserves in the world. This number makes Indonesia has the third largest number of nickel laterite reserves after New Caledonia (22.9\%) and the Philippines (17.4\%) (Dalfi et al., 2004). Because laterite has poor strength and high water content, it can have an impact on poor performance in the blast furnace and because of the high cost of the blast furnace, so it must take place optimally and effectively so that a pretreatment process is needed to suit the needs of one of the is with sintering

The sintering process is needed for laterite nickel ore before smelting in high furnaces, because laterite has poor strength and high water content. Sintering is a process where a mixture of ore, flux and coke is agglomerated (agglomerated) in the sinter plant to produce suitable sintered products in terms of composition, quality and granulometry to be used as a burden material in high furnaces (Cores et al., 2013). The sintering process is used to coagulate a mixture of ore (natural or synthetic), flux and coke so that the result is that sinter can withstand pressure and temperature conditions in the blast furnace (Cores et al., 2013). Because laterite nickel ore is a material for the production of Nickel Pig Iron (NPI), sintering is very important before melting, either in an blast furnace or electric arc furnace to supply quality raw materials with consistent chemical and physical properties. As for sintering laterite nickel ore, the high water content and material refactory resulting from the dehydroxylation process of magnesium silicate during sintering will inhibit the melting of the phase in sintering and bring problems such as poor sintering quality, low productivity and high energy consumption. The air flow rate has an important influence in the sintering process because the air will continue to supply oxygen to the combustion in the process of sintering laterite nickel ore (Li et al., 2013).

\section{Materials and Method}

\subsection{Materials}

This experiment uses raw materials including: laterite nickel ore, wood charcoal, limestone and kerosene. Laterite nickel ore used in this study was obtained from Southeast Sulawesi. The chemical content and phase of laterite nickel ore and limestone were obtained fromEDX analysis and XRD analysis. The EDX analysis results for laterite nickel ore and limestone are shown in Table 1. and Table 2. While the XRD analysis results for laterite nickel ore and limestone are shown in Fig. 1(a) and 1(b). On the other hand, the initial characterization of charcoal wood is carried out using proximate analysis. The results of the proximate analysis of wood charcoal are shown in Table 3.

Table 1. Chemical composition of laterite nickel ore

\begin{tabular}{ccccccc}
\hline Element & Fe & $\mathbf{O}$ & Si & Mg & Al & Ca \\
\hline \% wt & 42.01 & 25.89 & 17.78 & 5.91 & 2.50 & 3.36 \\
\hline Element & $\mathbf{N i}$ & $\mathbf{C r}$ & $\mathbf{S}$ & $\mathbf{C l}$ & $\mathbf{P}$ & $\mathbf{C o}$ \\
\hline \% wt & 1.59 & 1.29 & 0.27 & 0.20 & 0.18 & 0.02
\end{tabular}

Table 2. Chemical composition of limestone

\begin{tabular}{ccccccccc}
\hline Element & Ca & Fe & Si & C & O & Al & Mg & K \\
\hline \%wt & 43.01 & 1.87 & 6.51 & 11.02 & 33.93 & 2.43 & 0.57 & 0.66 \\
\hline
\end{tabular}

Table 3. Proximate analysis of charcoal

\begin{tabular}{cccccc}
\hline Parameter & $\begin{array}{c}\text { Moisture } \\
(\%, \mathbf{a r})\end{array}$ & $\begin{array}{c}\text { Ash Content } \\
(\%, \mathbf{a r})\end{array}$ & $\begin{array}{c}\text { Fixed Carbon } \\
(\%, \mathbf{a d b})\end{array}$ & $\begin{array}{c}\text { Volatile Matter } \\
(\%, \mathbf{a d b})\end{array}$ & $\begin{array}{c}\text { Calorific Value } \\
(\mathbf{C a l} / \mathbf{g r}, \mathbf{a d b})\end{array}$ \\
\hline$\% \mathrm{wt}$ & - & 1.7 & 59.4 & 35.2 & 6,783 \\
\hline
\end{tabular}


MATERIALS RESEARCH COMMUNICATIONS 1(1) (2020) 26-33

Fakhreza et. al.

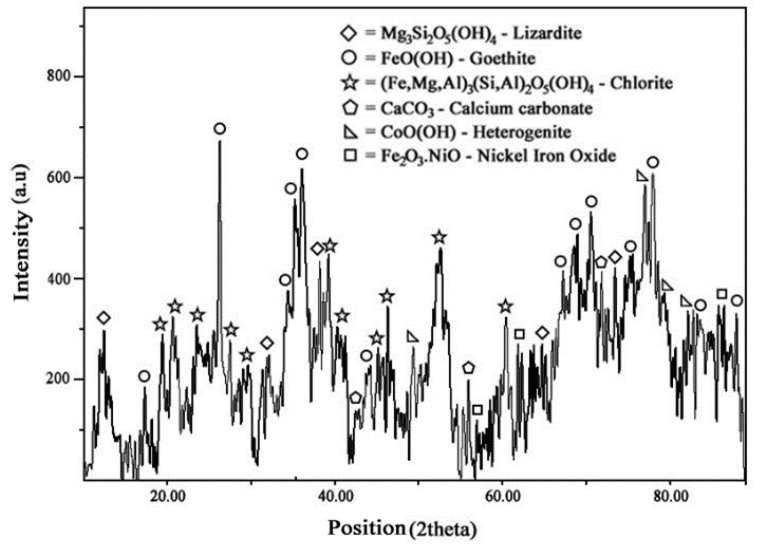

(a)

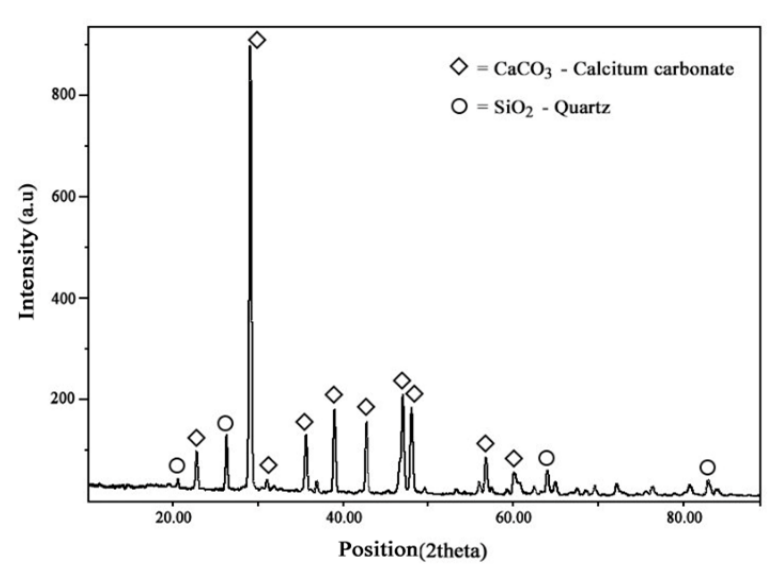

(b)

Fig 1. The XRD pattern of (a) Laterite nickel ore, and (b) Limestones.

\subsection{Method}

The raw material used consisted of laterite nickel ore, wood charcoal and limestone, which were sampled by crushing first and then filtering using a 50 mesh standard sieve. The raw material for laterite nickel and limestone ore is done by EDX analysis and XRD analysis. Wood charcoal is analyzed by the proximate analysis. The sintering furnace is located in Minerals and Materials Processing Lab., Dept. Of Materials Engneering ITS, Surabaya, Indonesia. First, laterite nickel ore was mixed with wood charcoal and limestone that has been weighed according to the composition calculation. Then in the sintering bed, wood charcoal is placed as fuel during the sintering process and combustion is carried out. After the fuel burns, the blower is turned on with a different variation of the air flow rate of $5.45 \mathrm{~m} 3 / \mathrm{min}, 8.22 \mathrm{~m} 3 / \mathrm{min}$ and $10.49 \mathrm{~m} 3 / \mathrm{min}$. Then the results of mixing of laterite nickel ore with wood charcoal and limestone were added to the sintering of the bed furnace and then start the holding time for 4 hours. After the sintering process with a holding time for 4 hours is finished, then cooled in the sintering of the bed furnace. The results of the sintering process so that the sintered results, the remaining charcoal and the remaining powder can be weighed using digital scales. The results of sintering use EDX, XRD and Drop Test to analyze the levels of content, phases that are formed and the strength of Sinter. The sinter yield can be calculated using Eq.1. and Eq.2.

$$
\begin{array}{ll}
\text { Return Fines } & =(\text { Fines }(\mathrm{kg}) / \text { Ore Mix in }(\mathrm{kg})) \times 100 \% \\
\text { Sinter Yield } & =100 \%-\text { Return Fines }
\end{array}
$$

\section{Results and Discussion}

\subsection{The effect of air flow rate on sinter yield}

Variations in air flow rate that will supply oxygen during the sintering process affect the sintering gain that can be produced during the sintering process. Based on Table 4 shows how the influence of variations in air flow rate on the yield obtained in the process of sintering laterite nickel ore.

Table 4. The effect of air flow rate on sinter yield

\begin{tabular}{ccccc}
\hline Airflow Rate $\left(\mathbf{m}^{\mathbf{3}} / \mathbf{m i n}\right)$ & $\begin{array}{c}\text { Ore Mix In } \\
(\text { Kg })\end{array}$ & Sinter Result $(\mathbf{K g})$ & $\begin{array}{c}\text { Fines } \\
(\mathbf{K g})\end{array}$ & Sinter Yield (\%) \\
\hline $\mathbf{5 . 4 5}$ & 45 & 5.63 & 23.70 & 47.33 \\
\hline $\mathbf{8 . 2 2}$ & 45 & 9.85 & 23.00 & 48.89 \\
\hline $\mathbf{1 0 . 4 9}$ & 45 & 12.08 & 17.40 & 82.33 \\
\hline
\end{tabular}


MATERIALS RESEARCH COMMUNICATIONS 1(1) (2020) 26-33

Fakhreza et. al.

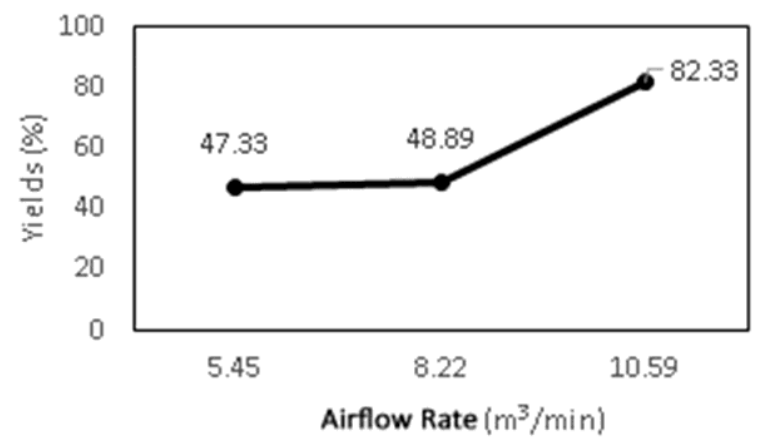

Fig 2. Effect of air flow rate on sinter yields.

Fig. 2 shows the sinter yield produced are higher along with the increase in air flow rate used in the sintering process of laterite nickel ore. The highest yield value was obtained at the air flow rate of $10.59 \mathrm{~m}^{3} / \mathrm{min}$, which was $82.33 \%$. This is because when the air flow rate is getting higher, the oxygen content in the sintering process will make the combustion process continue and also the sintering process temperature will be higher so that the sintering process will be faster and also produce more products (Loo and Wong, 2005). In addition, the higher the temperature during the sintering process, the more available energy is available so that the diffusion that occurs between the ore gets faster. This results in higher yield of sinter as temperature rise (Gupta, 2015).

\subsection{The effect of air flow rate on sinter strength}

The variation in air flow rate used in the sintering process affects the sintering strength obtained from the sintering process carried out. Based on Table 5 and Fig. 3, the effect of air flow on the sintered strength can be seen.

Table 5. The result of Drop Test

\begin{tabular}{cccc}
\hline Airflow Rate $\left(\mathbf{m}^{\mathbf{3}} / \mathbf{m i n}\right)$ & $\begin{array}{c}\text { Initial Weight } \\
\mathbf{( K g})\end{array}$ & $\begin{array}{c}\text { Final Weight } \\
\mathbf{( K g})\end{array}$ & $\begin{array}{c}\text { Shatter Index for } \mathbf{5} \mathbf{~ m m} \\
(\mathbf{\%})\end{array}$ \\
\hline $\mathbf{5 . 4 5}$ & 5.65 & 1.84 & 32.45 \\
\hline $\mathbf{8 . 2 2}$ & 9.85 & 4.32 & 43.86 \\
\hline $\mathbf{1 0 . 4 9}$ & 12.08 & 7.88 & 65.24 \\
\hline
\end{tabular}

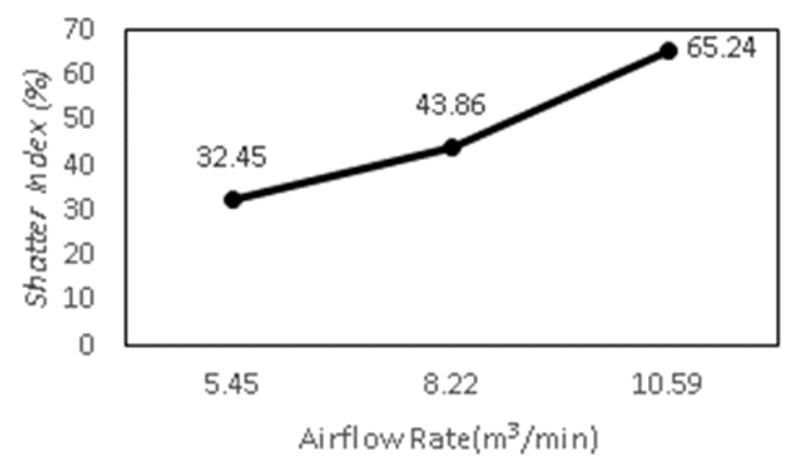

Fig 3. Effect of air flow rate on sinter strength.

From Table 5 and Fig. 3, the value of the Shatter Index (SI) shows that the air flow rate used during the sintering process of lateritic nickel ore increases. The biggest SI was obtained at an air flow rate of $10.59 \mathrm{~m}^{3} / \mathrm{min}$ which had an initial weight of $12.08 \mathrm{~kg}$, a final weight of $7.88 \mathrm{~kg}$ and SI of $65.24 \%$. Then, SI the second largest 
MATERIALS RESEARCH COMMUNICATIONS 1(1) (2020) 26-33

Fakhreza et. al.

was obtained at an air flow rate of $8.22 \mathrm{~m}^{3} / \mathrm{min}$ which had an initial weight of $9.85 \mathrm{~kg}$, a final weight of $4.32 \mathrm{~kg}$ and SI of $43.86 \%$. Whereas the smallest SI was obtained at an air flow rate of $5.45 \mathrm{~m} 3 / \mathrm{min}$ which had an initial weight of $5.67 \mathrm{~kg}$, final weight of $1.84 \mathrm{~kg}$ and SI of $32.45 \%$. So, sintered which has the best strength in sequence is at an air flow rate of $10.59 \mathrm{~m}^{3} / \mathrm{min}$, then $8.22 \mathrm{~m}^{3} / \mathrm{min}$ and the last is $5.45 \mathrm{~m}^{3} / \mathrm{min}$. One of the high-quality sinters has high strength, namely through the Shatter Index ranging from $60-80 \%$ (Fulgenzio, 2017).

When the air flow rate gets higher, the higher the temperature and the heat in the bed, the higher it makes the more melt that is formed which causes the strength of the sintering to sintering laterite nickel ore higher (Fouzi et al., 2006). The heat obtained from this high temperature can make these two ore particles bound through diffusion bonds. Slags that have low melting points such as $\mathrm{SiO}_{2}$ and $\mathrm{CaO}$ also make sinters have better strength (Gupta, 2015).

Sintering is a brittle and porous material. The more porous the surface of the sintered makes the strength of the sintering weaker. Increasing temperature greatly affects the strength of the sintered. When the sintering temperature increases, the porosity in the sintering decreases, but the density of the sintering increases so that the strength of the sintering becomes even better (Purwanto et al., 2018). When sintering continues until the temperature of $1275^{\circ} \mathrm{C}$, the Silico Ferrite of Calcium Alumina (SFCA) phase formed becomes more numerous. SFCA at higher temperatures occurs densification (increase in density of sintered) and more and more melts are formed. The SFCA phase is very helpful in increasing the strength of sinters. The surface morphology of the needle-like SFCA is very helpful to prevent cracking so that the strength of the sintered will increase (Jordaan, 2006).

\subsection{The effect of air flow rate on Ni content}

The variation of air flow in the sintering process of laterite nickel ore also affects the $\mathrm{Ni}$ content found in sintered. Based on Fig. 4, it can be seen how the effect of the air flow rate on the Ni content found in Sinter.

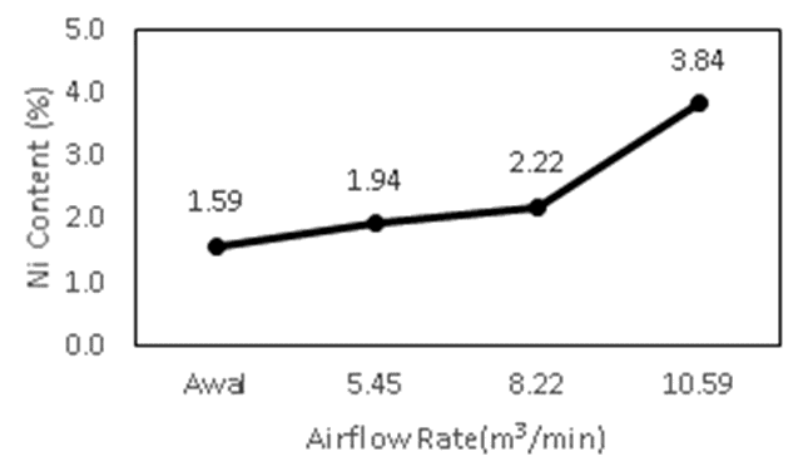

Fig 4. Effect of air flow rate on Ni content of sinter.

From Fig. 4, it can be seen at the beginning in laterite nickel ore, Ni content which is equal to $1.59 \%$. When sintering at an air rate of $5.45 \mathrm{~m}^{3} / \mathrm{min}$, the Ni content contained in sintered rose to $1.94 \%$ with an increase of $0.35 \%$ from the initial state. Then at the air flow rate of $8.22 \mathrm{~m}^{3} / \mathrm{min}$, the Ni content contained in the sintering becomes higher, which is $2.22 \%$ with an increase in content of $0.63 \%$ from the initial state. And at the highest air flow rate of $10.49 \mathrm{~m}^{3} / \mathrm{min}$, the $\mathrm{Ni}$ content contained in the sintering becomes higher, which is $3.84 \%$ with an increase of $2.25 \%$ from the initial state.

The increase in Ni content in Sintered products in the process of sintering laterite nickel ore is due to dehydroxylation in the lizardite $\left[\left(\mathrm{Mg}, \mathrm{Ni}_{3}\right)_{3} \mathrm{Si}_{2} \mathrm{O}_{5}(\mathrm{OH})_{4}\right]$ compound at a temperature of around $700{ }^{\circ} \mathrm{C}$ so that the compound will release hydroxide $(\mathrm{OH})$ bonds. This reaction will cause the separation of $\mathrm{SiO}_{2}, \mathrm{NiO}$ and $\mathrm{MgO}$ compounds from Lizardite (Crundwell, 2011). Increasing Ni content is also caused by decreasing Fe content in sinter. In the process of reducing laterite nickel ore, the increase of $\mathrm{Ni}$ and Fe levels affects each other, meaning that decreasing Fe content will cause Ni content (Kim et al., 2010). 
MATERIALS RESEARCH COMMUNICATIONS 1(1) (2020) 26-33

Fakhreza et. al.

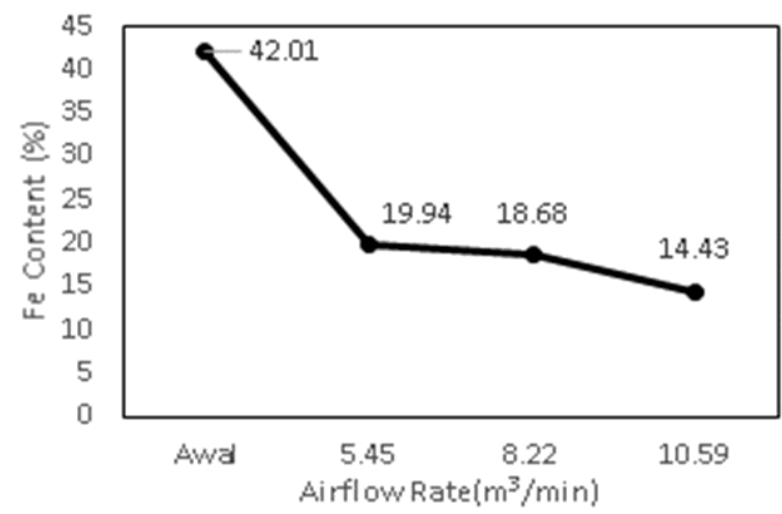

Fig 5. Effect of air flow rate on Fe content of sinter.

Fig. 5 shows the Fe content in laterite nickel ore decreases in sintered products in the process of sintering laterite nickel ore. In the initial conditions in laterite nickel ore in table 1. Fe content contained in laterite nickel ore is equal to $42.01 \%$. Sintered results at various air flow rates of $5.45 \mathrm{~m}^{3} / \mathrm{min}$, have Fe content of $19.94 \%$, at air flow rates of $8.22 \mathrm{~m}^{3} / \mathrm{min}$ having Fe content of $18.68 \%$ and at the highest air flow rate of $10.59 \mathrm{~m}^{3} / \mathrm{min}$ at $14.43 \%$. This decrease is also caused by a high sintering base which is an effect of addition from Limestone and charcoal. Increasing the base also indicates an increase in the mass of $\mathrm{Ca}$ and $\mathrm{Mg}$ in sintered which will cause the $\mathrm{Fe}$ content in the sinter to decrease so that the Ni content of the sintering increases (Yang et al., 2015).

\subsection{The effect of air flow rate on sinter phases}

The phase identification of sintered from the process of sintering laterite nickel ore produced from each variable air flow rate was tested by the PAN Analytical XRD machine. The XRD test results for each variable are shown in Fig. 6.

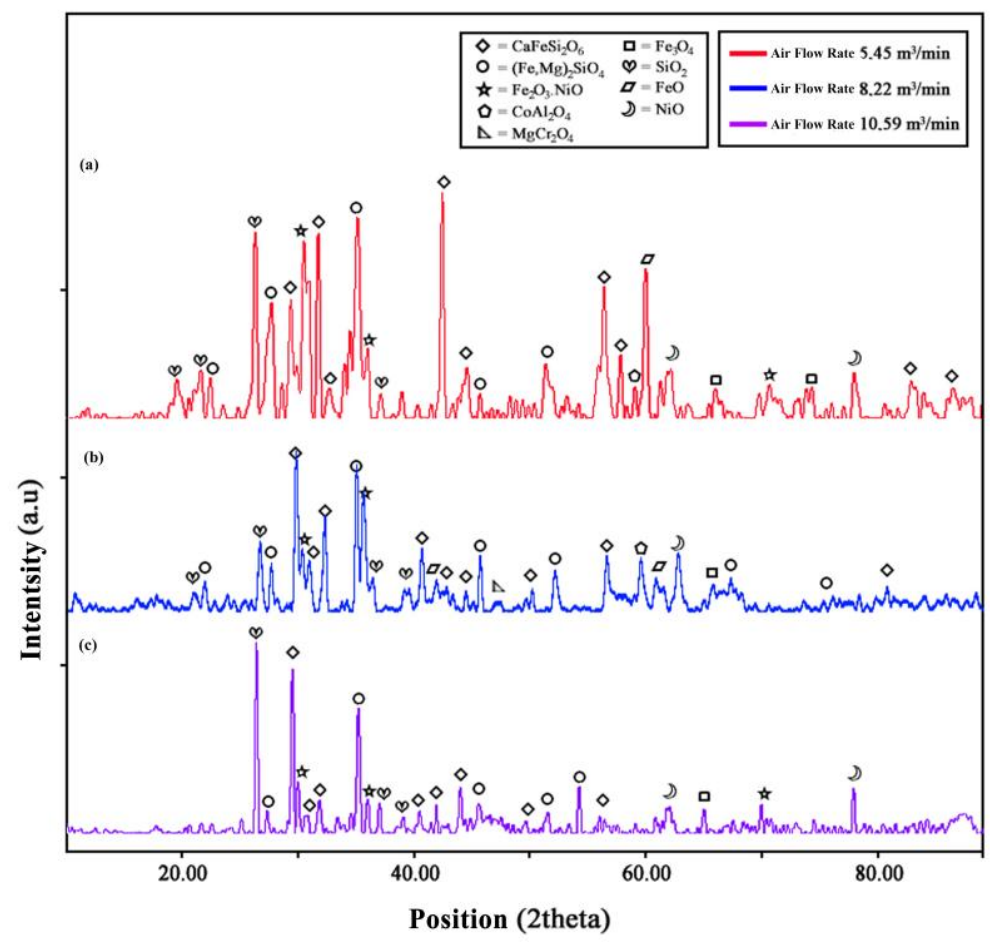

Fig. 6. The XRD result of sinter. 
MATERIALS RESEARCH COMMUNICATIONS 1(1) (2020) 26-33

Fakhreza et. al.

Based on the peak contained in the XRD results in Fig. 6, the sintered results of sintering of laterite nickel ore with air air flow rate of $5.45 \mathrm{~m}^{3} / \mathrm{min}$ revealed the major phase of sintered namely Pyroxene $\left(\mathrm{CaFeSi}_{2} \mathrm{O}_{4}\right)$ and Olivine $\left((\mathrm{Fe}, \mathrm{Mg})_{2} \mathrm{SiO}_{4}\right)$ and several phases minor from sintered are Nickel Iron Oxide $\left(\mathrm{Fe}_{2} \mathrm{O}_{3}\right.$. NiO), Magnetite $\left(\mathrm{Fe}_{3} \mathrm{O} 4\right)$, Wustite $(\mathrm{FeO})$, Spinnel $\left(\mathrm{CoAl}_{2} \mathrm{O}_{4}\right)$, Quartz $\left(\mathrm{SiO}_{2}\right)$ and Nickel Oxide $(\mathrm{NiO})$

Based on the peak contained in the XRD results in Fig. 6, the sintered resulting from sintering of laterite nickel ore with air air flow rate $8.22 \mathrm{~m}^{3} / \mathrm{min}$ revealed the major phase of sintered namely Pyroxene $\left(\mathrm{CaFeSi}_{2} \mathrm{O}_{4}\right)$ and Olivine $\left((\mathrm{Fe}, \mathrm{Mg})_{2} \mathrm{SiO}_{4}\right)$ and several phases minor from sintered are Nickel Iron Oxide $\left(\mathrm{Fe}_{2} \mathrm{O}_{3} \cdot \mathrm{NiO}\right)$, Magnetite $\left(\mathrm{Fe}_{3} \mathrm{O}_{4}\right)$, Wustite $(\mathrm{FeO})$, Spinnel $\left(\mathrm{CoAl}_{2} \mathrm{O}_{4}\right)$, Quartz $\left(\mathrm{SiO}_{2}\right)$, Nickel Oxide $(\mathrm{NiO})$ and Magnesiochromitte $\left(\mathrm{MgCr}_{2} \mathrm{O}_{4}\right)$. Magnesiochromitte phase $\left(\mathrm{MgCr}_{2} \mathrm{O}_{4}\right)$ was formed because the Magnesiochromitte phase $\left(\mathrm{MgCr}_{2} \mathrm{O}_{4}\right)$ formed from the bond between $\mathrm{MgO}$ and $\mathrm{Cr}_{2} \mathrm{O}_{3}$ occurred at a fairly high temperature of around $1100{ }^{\circ} \mathrm{C}$ (Bamford and Tipper, 2008) as in Eq.3, so that in the XRD results with variations in air flow rate of $5.45 \mathrm{~m}^{3} / \mathrm{min}$ there is no Magnesiochromitte phase $\left(\mathrm{MgCr}_{2} \mathrm{O}_{4}\right)$ indicating the temperature during the sintering process has not reached $1100{ }^{\circ} \mathrm{C}$.

$$
\mathrm{MgO}(\mathrm{s})+\mathrm{Cr}_{2} \mathrm{O}_{3}(\mathrm{~s})=\mathrm{MgO} \cdot \mathrm{Cr}_{2} \mathrm{O}_{3}(\mathrm{~s})
$$

Based on the peak contained in the XRD results in Figure 6, the sintered results of sintering of laterite nickel ore with air air flow rate of $10.59 \mathrm{~m}^{3} / \mathrm{min}$ revealed the major phase of sintered namely Pyroxene $\left(\mathrm{CaFeSi}_{2} \mathrm{O}_{4}\right)$ and Olivine $\left((\mathrm{Fe}, \mathrm{Mg})_{2} \mathrm{SiO}_{4}\right)$ and several phases minor from sintered are Nickel Iron Oxide $\left(\mathrm{Fe}_{2} \mathrm{O}_{3} \cdot \mathrm{NiO}\right)$, Magnetite $\left(\mathrm{Fe}_{3} \mathrm{O}_{4}\right)$, Quartz $\left(\mathrm{SiO}_{2}\right)$ and Nickel Oxide $(\mathrm{NiO})$. The absence of the Wustite $(\mathrm{FeO})$ phase is due to the less magnetite phase, so that wustite which is the result of reduction of magnetite $\left(\mathrm{Fe}_{3} \mathrm{O}_{4}\right)$ by $\mathrm{CO}$ gas originating from the Boudouard reaction becomes difficult to form (Umadevi et al., 2014).

The Olivine ((Fe, $\mathrm{Mg})_{2} \mathrm{SiO}_{4}$ phase) is formed because $\mathrm{FeO}$ which binds to $\mathrm{MgO}$ and $\mathrm{SiO}_{2}$ at $975^{\circ} \mathrm{C}$ as in Eq.4 (Yang et al., 2015).

$$
\mathrm{FeO}(\mathrm{s})+\mathrm{SiO}_{2}(\mathrm{~s})+\mathrm{MgO}(\mathrm{s})=(\mathrm{Fe}, \mathrm{Mg})_{2} \mathrm{SiO}_{4}(\mathrm{~s})
$$

Pyroxene phase is formed because at high temperatures around $1100{ }^{\circ} \mathrm{C}$, Wustite $(\mathrm{FeO})$ will bind to $\mathrm{CaO}$ and $\mathrm{SiO}_{2}$ which will form Pyroxene $\left(\mathrm{CaFeSi}_{2} \mathrm{O}_{4}\right)$ as in Eq.5 [16].

$$
\mathrm{Fe}_{2} \mathrm{O}_{3} \cdot \mathrm{CaO}(\mathrm{s})+\mathrm{SiO}_{2}(\mathrm{~s})+\mathrm{Al}_{2} \mathrm{O}_{3}(\mathrm{~s})=\mathrm{Fe}_{2} \mathrm{O}_{3} \cdot \mathrm{CaO} \cdot \mathrm{SiO}_{2} \cdot \mathrm{Al}_{2} \mathrm{O}_{3}(\mathrm{~s})
$$

When the air flow rate gets higher, the temperature produced is higher and the reaction that occurs at that temperature gets faster so that the Pyroxene that is formed is increasing and the wustite phase is reduced because it forms pyroxene [15].

\section{Conclusions}

The higher the air flow rate, the better sintering obtained from the sintering process. The highest yield of sintered results was obtained in the sintering process with an air flow rate of $10.59 \mathrm{~m}^{3} / \mathrm{min}$ which was $12.08 \mathrm{~kg}$ with powder of $17.4 \mathrm{~kg}$ and yield of $82.33 \%$. The higher the air flow rate, the better the sinter strength of the sintering process. The highest sintering strength is at the air flow rate of $10.59 \mathrm{~m}^{3} / \mathrm{min}$ which has a Shatter Index of $65.23 \%$. The higher the air flow rate, the higher the Ni content of sintered as a result of the sintering process. The highest increase in Ni content was found at the air flow rate of $10.59 \mathrm{~m}^{3} / \mathrm{min}$, which is $2.25 \%$ with the Ni content in sintered which is $3.84 \%$. The phase formed in sintered from the sintering process at each air velocity variation tends to be the same which has the major phase of sintered in the form of Pyroxene $\left(\mathrm{CaFeSi}_{2} \mathrm{O}_{4}\right)$ and Olivine $\left((\mathrm{Fe}, \mathrm{Mg})_{2} \mathrm{SiO}_{4}\right)$.

\section{References}

Bamford, C.H, Tipper, C.F.H. 2008. "Comprehensive Chemical Kinetics". New York : Elsevier.

Barkas J., 2010. "Drivers and risks for nickel demand”, 7th International China Nickel Conference, ,Shangai, China. 
MATERIALS RESEARCH COMMUNICATIONS 1(1) (2020) 26-33

Fakhreza et. al.

Cores, Alejandro., Verdeja, Luis Felipe., Ferreira, Serafin., Bustinza, Inigo Ruiz dan Mochon, Javier. 2013. "Iron Ore Sintering Part1. Theory and Practice of The Sintering Process". Dyna. Medellin,Columbia, 80, 152

Crundwell, Frank K., 2011 . "Extractive Metallurgy of Nickel, Cobalt and Platinum-Group Metals". Amsterdam:Elsevier Ltd,

Dalvi, Ashok D, W Gordon Bacon, and Robert C Osborne.2004. "The Past and The Future of Nickel Laterites". International Convention : 1-7.

Fouzi, Saad M., Kahlifa, M.G., Ahmed, Y.M.Z., Mohamed, F.M., Shalabi, M.E.H., 2006. "Sintering of Egyptian Iron Ore”. Górnictwo i Geoinżynieria, 30, pp. 91-107

Fulgenzio, Andre, 2017. "Next Generation Sintering Technologies Latest Developments to Achieve Real CostEfficiency in Sinter Production". Austria: SIEMENS VAI Metals Technologies GmbH \& Co.

Gupta,R.C. , 2015. "Theory and Laboratory Experimental in Ferrous Metallurgy". Raj Press: New Delhi, India

Jordaan, Willem Jacobus. 2006. "The variation of sinter strength in the sinter bed due to the mineral phase distribution". Theses of University of Pretoria: South Africa

Kim, J., Dodbiba, G., Tanna, H., Okayaa, K., Matsuo, S., Fujita, T., 2010 . "Calcination of low-grade laterite for concentration ofNi by magnetic separation". Minerals Engineering, $23: 282-288$.

Li, G., Zhi, Q., Rao, M., Zhang, Y., Cai, W. and Jiang, T.2013. "Effect of basicity on sintering behavior of saprolitic nickel laterite in air". Powder Technology, 249, pp.212-219

Loo, C.E dan Wong, D.J., 2005 . "Fundamental Factors Determining Laboratory Sintering Results”, ISIJ International, 4, pp.449-458

Purwanto, H. , Rozhan, A.N., Zakiyyudin, A., Mohammad, A.S., 2018. "Effect of temperature on porosity of iron ore sinter with biochar derived from EFB". IOP Conf. Series: Materials Science and Engineering, 290, 012012

Umadevi,T. , Brahmacharyulu, A., Sah, R., Mahapatra, P.C., 2014. "Influence of Sinter Grate Suction Pressure (Flame Front Speed) on Microstructure, Productivity and Quality of Iron Ore Sinter". Ironmaking and Steelmaking, 41, pp. 410-417

Yang, S., Zhou, M., Jiang, T., Wang, Y., Xue, X., 2015. "Effect of Basicity on Sintering behavior of lowtitanium vanadium-Titanium Magnetite". Trans. Nonferrous Met. Soc. : China, 25, pp. 2087-2094 